\title{
Hyperbaric pressure at room temperature increases post-harvest preservation of the tomato cultivar 'Débora'
}

\author{
Carlos Inestroza-Lizardo $^{\mathrm{a}, \mathrm{b}, *}$, Ben-Hur Mattiuz ${ }^{\mathrm{a}}$, Josiane Pereira da Silva ${ }^{\mathrm{c}}$, Vanessa Cury Galati ${ }^{\mathrm{d}}$, \\ Vanessa Voigt ${ }^{\mathrm{a}}$ \\ ${ }^{a}$ Sao Paulo State University (Unesp), School of Agricultural and Veterinarian Sciences, Jaboticabal, São Paulo, Brazil \\ b Departamento de Tecnología de Alimentos, Universidad Nacional de Agricultura, Carretera a Dulce Nombre de Culmí, km 215, Barrio El Espino, Catacamas, Honduras \\ c Universidade Federal Rural da Amazonia (UFRA), Departamento de Agronomia, Parauapebas, Pará, Brasil \\ d Centro Universitário de Votuporanga/UNIFEV, Votuporanga, SP, Brasil
}

\section{A R T I C L E I N F O}

\section{Keywords:}

Solanum lycopersicum L

Firmness

Color

Lycopene

Ripening

\begin{abstract}
A B S T R A C T
The aim of the present study was to evaluate the effect of the application of hyperbaric pressure at room temperature $\left(23 \pm 1{ }^{\circ} \mathrm{C}\right)$ for 2,4 or $6 \mathrm{~d}$, followed by $2 \mathrm{~d}$ under ambient conditions $\left(23^{\circ} \mathrm{C}, 50 \%\right.$ relative humidity, $100 \mathrm{kPa}$ ), on the physical, chemical and metabolic characteristics of the tomato cultivar 'Débora'. The following pressures were tested: 100 (control), 200, 400, 600 and $800 \mathrm{kPa}$. Tomatoes subjected to 600 or $800 \mathrm{kPa}$ for $6 \mathrm{~d}$ presented lower weight loss (up to 80\%) and 1.2 times greater firmness than control tomatoes. Hyperbaric pressure did not decrease the tomato respiration rate. However, the initial tomato color was maintained with increasing applied pressure, and pressure decreased tomato lycopene synthesis by up to $57 \%$. Normal tomato ripening was not negatively affected by the application of hyperbaric pressure. The present results show that application of hyperbaric pressure up to $800 \mathrm{kPa}$ at $23^{\circ} \mathrm{C}$ delays the ripening of the tomato cultivar 'Débora' and results in longer shelf life.
\end{abstract}

\section{Introduction}

The tomato (Solanum lycopersicum L.) is one of the most widely grown and consumed vegetables in the world and is therefore of great commercial importance (Beckles, 2012; Azabou et al., 2016). In addition, tomatoes synthesize a large variety of phytochemicals with high antioxidant power; many of these vitamins, carotenoids and phenolic compounds are associated with decreased risk of chronic diseases such as cardiovascular disease and cancer (Del Giudice et al., 2015; Stajčić et al., 2015). The tomato is a climacteric fruit that is usually harvested at the physiological maturation stage (green-ripe) to facilitate preservation and minimize losses during handling and transportation (Wang et al., 2008). At room temperature $\left(23^{\circ} \mathrm{C}\right)$, tomatoes ripen quickly, changing in color, firmness, taste and chemical composition and undergoing increased water loss, which significantly decreases their commercialization period (Javanmardi and Kubota, 2006).

The tomato cultivar 'Débora' presents oblong fruit that are reddish when ripe; these are generally consumed fresh due to their excellent organoleptic characteristics (Nascimento et al., 2013). However, the fruit of this cultivar has a short shelf life compared to other cultivars; its shelf life is less than one week when the fruit is stored at $24^{\circ} \mathrm{C}$.
A variety of technologies, the most common of which is refrigeration, are currently used to preserve fruit quality and prolong potential shelf life. Storage under refrigeration (at temperatures of $10-15^{\circ} \mathrm{C}$ ) effectively decreases the respiration rate of tomatoes, preserves the general quality of the fruit, and increases shelf life (Saltveit, 2003). However, refrigeration incurs high energy costs and cannot be implemented in regions without a supply of electrical energy (Raghavan et al., 2004).

Post-harvest hyperbaric treatment consists of subjecting fruit and vegetables to pressures between $100 \mathrm{kPa}$ and $1000 \mathrm{kPa}$ through a constant flow of compressed air (Goyette et al., 2011). Hyperbaric treatment acts instantaneously and uniformly on each item of produce, independently of its size, shape or composition, and is microbiologically safe. In addition, pressure treatment requires only $2-6 \%$ of the energy needed for refrigeration since pressurization does not need to be instantaneous and little energy is required to maintain pressure during storage (Vigneault et al., 2012).

Recent studies have shown that the use of hyperbaric pressure may slow metabolic processes in some vegetables, preserving their qualitative characteristics. Baba and Ikeda (2003), reported decreased $\mathrm{CO}_{2}$ and $\mathrm{C}_{2} \mathrm{H}_{4}$ production in Japanese apricot (Prunus mume L.) fruit stored at

\footnotetext{
* Corresponding author at: Departamento de Tecnología de Alimentos. Universidad Nacional de Agricultura. Catacamas, Honduras.

E-mail address: cinestrozalizardo@gmail.com (C. Inestroza-Lizardo).
} 
$5{ }^{\circ} \mathrm{C}$ and $500 \mathrm{kPa}$ for $5 \mathrm{~d}$; delayed ripening and decreased fresh weight loss were also noted. Tomatoes stored at $13^{\circ} \mathrm{C}$ and $900 \mathrm{kPa}$ for 5,10 or $15 \mathrm{~d}$ presented a $22 \%$ decrease in respiration rate compared to controls stored at $13{ }^{\circ} \mathrm{C}$ and $100 \mathrm{kPa}$ (Goyette et al., 2012b). In addition, the authors also observed delayed lycopene synthesis and maintenance of firmness compared to fruit maintained under ambient pressure. Liplap et al. (2013a), observed that tomatoes stored at $20^{\circ} \mathrm{C}$ and $700-900 \mathrm{kPa}$ for $4 \mathrm{~d}$ presented respiration rates similar to controls $\left(20^{\circ} \mathrm{C}\right.$ and $100 \mathrm{kPa}$ ). However, the pressurized tomatoes remained greener and more turgid.

Although promising results of post-harvest hyperbaric treatment for the preservation of some fruit and vegetables have been reported, the number of studies in this area is still limited, and research in the field is still exploratory. No studies have been reported for specific regions, production conditions or varieties; thus, the application of pressure treatment as a post-harvest alternative has been limited. The aim of the present study was to evaluate the effect of hyperbaric pressure treatment at room temperature $\left(23^{\circ} \mathrm{C}\right)$ on the physical, chemical and metabolic characteristics of the tomato cultivar 'Débora'.

\section{Material and methods}

\subsection{Plant material}

Fruit of the tomato cultivar 'Débora' were used. The fruit originated from commercial farms in the region of Ribeirão Preto, state of São Paulo, Brazil $\left(21^{\circ} 20^{\prime} 18^{\prime \prime} \mathrm{S}\right.$ and $47^{\circ} 43^{\prime} 58^{\prime \prime} \mathrm{W}, 793 \mathrm{~m}$ altitude) and were harvested at the green-ripe stage according to the classification of López Camelo and Gómez (2004). The fruit were transported for $1 \mathrm{~h}$ to the Laboratory of Post-Harvest Technology on the Jaboticabal Campus of Universidade Estadual Paulista (São Paulo State University). The fruit were washed with potable water and neutral detergent, disinfected with $200 \mathrm{mg} \mathrm{L}^{-1}$ sodium dichloroisocyanurate (Sumaveg", São Paulo, Brazil) for $5 \mathrm{~min}$, dried at $23^{\circ} \mathrm{C}$ on a paper-lined surface, and selected to guarantee homogeneity in size, shape, and color and to ensure the absence of damage and disease.

\subsection{Hyperbaric system}

The experiments were conducted using a hyperbaric pressure system as described by Goyette et al. (2011) and Liplap et al. (2014), (Fig. 1). The system consists of 6 steel vessels connected in an open circuit through which a constant flow of compressed air circulates to maintain constant concentrations of oxygen (21\%) and nitrogen (78\%). Carbon dioxide is adsorbed prior to inflow by passing the air through a chamber containing calcium oxide. The vessels had an interior volume of $10.75 \mathrm{~L}$ (approximate capacity 20 tomatoes) and were closed with a bolted steel lid. Each lid was equipped with a pressure regulator at the entrance point and a needle valve at the exit point of each vessel to regulate the air pressure and airflow, respectively, in each vessel. A safety relief valve was also installed on the lid to prevent pressure overload. The inlet of the vessel was connected to a 250-L compressed air cylinder (Schulz, model MSV 20 MAX, Joinville, Santa Catarina state, Brazil) for compressed air supply. Air flow was measured using a flow meter with a measuring range of $5-2000 \mathrm{~mL} \mathrm{~min}^{-1} \pm 12 \mathrm{~mL} \mathrm{~min}^{-1}$ (Bronkhorst $^{\mathrm{TM}}$, Ruurlo, Netherlands). $\mathrm{CO}_{2}$ concentration was measured using an infrared gas analyzer (Guardian ${ }^{\circledR}$ Plus, Kirkton Campus, Livingston, England). The flow meter, control valve and $\mathrm{CO}_{2}$ gas analyzer were connected to a data acquisition and control card (Personnel DAQ 3000, Cleveland, OH, USA) and a laptop computer. Pressure, air flow rate and $\mathrm{CO}_{2}$ level were recorded using DasyLab ${ }^{\circ}$ software (Measurement Computing Corporation, Norton, MA, USA). The respiration rate in real time was calculated using the following equation:

$R R=\frac{\Delta \mathrm{CO}_{2} \times Q}{w}$

in which $\Delta \mathrm{CO}_{2}$ is the difference between the $\mathrm{CO}_{2}$ concentration at the vessel entrance and the $\mathrm{CO}_{2}$ concentration at the vessel exit, $Q$ is the air flow rate, and $w$ is the produce weight.

\subsection{Treatment application}

Sixty tomatoes (average weight $130 \mathrm{~g}$ ) were selected based on the parameters described in Section 2.1. Ten tomatoes were used to determine the initial fruit quality and to confirm fruit homogeneity (Table 1); the remaining fifty tomatoes were divided into 5 groups of 10 each. Each group of tomatoes was placed in a sealed vessel and subjected to one of the following pressures: 100 (control), 200, 400, 600 or $800 \mathrm{kPa}$. The relative humidity (RH) inside the vessels was maintained at $95 \pm 2.5 \%$ and was monitored every $30 \mathrm{~min}$ using a data logger (HOBO Prov2 U-23-001).

The tomatoes remained under hyperbaric pressure (HP) for 2, 4 or $6 \mathrm{~d}$ at $23 \pm 1{ }^{\circ} \mathrm{C}$. At the end of each period, the vessels were automatically depressurized for $2 \mathrm{~h}, 5$ tomatoes (experimental unit) were removed from each vessel and immediately evaluated, and the

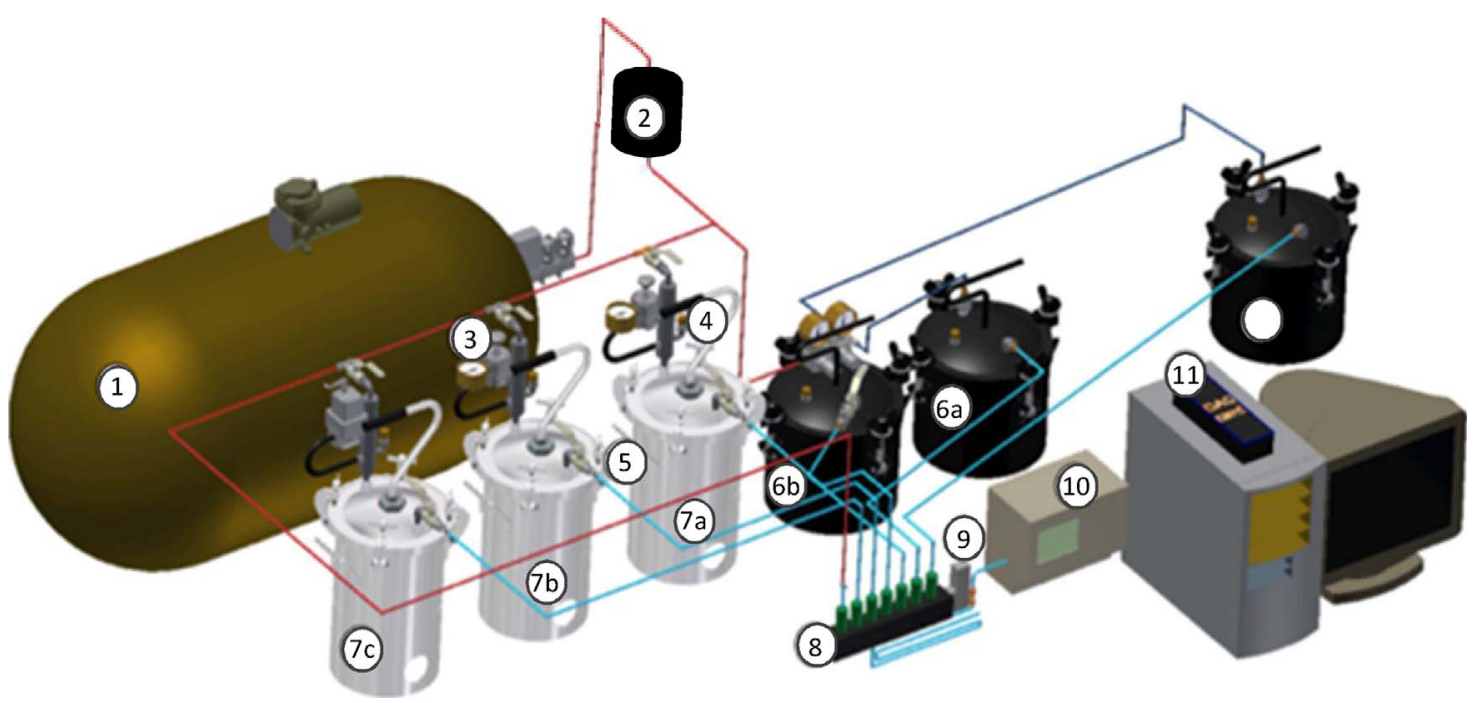

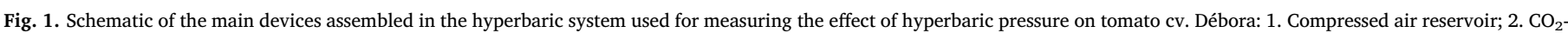

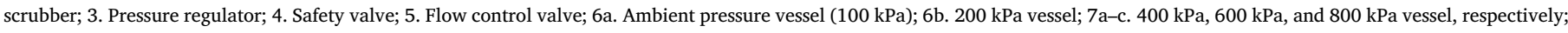
8. Valve-manifold assembly; 9. Airflow meter; 10. Infrared gas analyzer; 11. Data acquisition board and computer. 
Table 1

Initial quality parameters of the tomato cultivar 'Débora' prior to application of hyperbaric pressure.

\begin{tabular}{ll}
\hline Parameters & Value \\
\hline Firmness (N) & $35.21 \pm 1.45$ \\
Color & $54.89 \pm 0.79$ \\
Lightness ( $\left.{ }^{*}\right)$ & $28.01 \pm 0.61$ \\
chromaticity (C*) & $112.45 \pm 1.66$ \\
Hue angle (H) & $2.60 \pm 0.35$ \\
Ethylene production $\left(\mathrm{ng} \mathrm{kg}^{-1} \mathrm{~S}^{-1}\right)$ & $4.29 \pm 0.08$ \\
TSS (\%) & $0.29 \pm 0.01$ \\
TA (g $100 \mathrm{~g}^{-1}$ pulp) & $14.77 \pm 0.63$ \\
TSS: TA ratio & $0.40 \pm 0.09$ \\
Lycopene content (mg $100 \mathrm{~g}^{-1}$ pulp) & \\
\hline
\end{tabular}

Values represent the mean and standard error (SE) of nine replicates consisting of 10 tomatoes each.

remaining 5 were stored for $2 \mathrm{~d}$ at $23 \pm 1{ }^{\circ} \mathrm{C}, 50 \% \mathrm{RH}$ and $100 \mathrm{kPa}$ to monitor the evolution of tomato ripening. Except for the respiration rate, measurements were performed at the end of each HP application period $(2,4$ and $6 \mathrm{~d})$ and at $\mathrm{HP}+2 \mathrm{~d}(2+2,4+2$ and $6+2 \mathrm{~d})$. Three replicates were performed for each period of HP application and for each set of samples that underwent $2 \mathrm{~d}$ storage, yielding a total of 9 collections.

\subsection{Physical, metabolic and chemical analyses}

\subsubsection{Weight loss}

Fruit weight was measured before the fruit were placed in the vessels (initial weight) and after each storage and commercial simulation period using an electronic scale with a measuring range of 50-6000 g $\pm 2 \mathrm{~g}$ (Filizola, BP6, São Paulo, Brazil). Weight loss was calculated as the difference between the initial and the final weights divided by the initial weight and was expressed as percentage of the initial weight.

\subsubsection{Firmness}

Firmness was measured using a digital penetrometer with an 8-mm tip (5-200 N \pm 1 N; Impac, IP-90DI, São Paulo, SP, Brazil). Five fruit of each replicate were measured on opposite sides of their equatorial regions after removing the fruit skin. Firmness was expressed as the force in Newtons (N) needed to penetrate the tomato pulp.

\subsubsection{Color}

Tomato color was measured using a portable colorimeter (Minolta CR-400, Minolta Corp., Tokyo, Japan) with illuminant D65 at a viewing angle of $0^{\circ}$ after calibration with a standard color (white), using the CIELab system. Lightness ( $\mathrm{L} ; 0=$ black, $100=$ white), chromaticity $\left(C^{*}\right)$ and Hue angle $\left(h^{\circ}\right)$ were determined. Five fruit of each replicate were measured, with two measurements per fruit at two opposite points along the equatorial region.

\subsubsection{Respiration rate and ethylene production}

The $\mathrm{CO}_{2}$ concentrations in each vessel were measured during hyperbaric storage. The tomato respiration rate was automatically calculated in real time as described in Section 2.2 and was expressed in $\mathrm{mg}$ $\mathrm{CO}_{2} \mathrm{~kg}^{-1} \mathrm{~h}^{-1}$.

Tomato ethylene production was determined at the end of the experiments $(2+2,4+2$ and $6+2 d)$. Five tomatoes were placed in a 3.2-L glass container with a rubber septum cap. One hour after sealing, $500-\mu \mathrm{L}$ gas samples were collected from inside the containers (head space) using a gas chromatography syringe (SGE, Analytical Science). Three replicates were performed per treatment. The sample was injected into a gas chromatograph (Trace GC Ultra, Thermo Scientific) equipped with a flame ionization detector (FID) and a 2-m-long Porapak $\mathrm{N}$ capillary column. The column temperature was set to $80^{\circ} \mathrm{C}$, and hydrogen was used as the carrier gas $\left(35 \mathrm{~mL} \mathrm{~min}^{-1}\right)$. The working temperatures were $110{ }^{\circ} \mathrm{C}, 250^{\circ} \mathrm{C}$ and $200{ }^{\circ} \mathrm{C}$ for the column, detector, and injector, respectively. The GC was calibrated using a $1 \mu \mathrm{mol} \mathrm{mol}{ }^{-1}$ ethylene commercial standard (White Martins, Brazil). Ethylene production was expressed as $\mathrm{ng} \mathrm{kg}^{-1} \mathrm{~S}^{-1}$.

\subsubsection{Total soluble solids (TSS) and titratable acidity (TA)}

Total soluble solid contents and titratable acidity were determined by analyzing tomato pulp that had been homogenized using a portable food processor (Mondial Super Centrifuga Premium). Total soluble solids were determined in the liquid obtained from the homogenized pulp using a manual digital refractometer $(0-45 \pm 0.1 \%$ measuring range; Atago Palette, PR-101) and were expressed as a percentage (Aguayo et al., 2013). Titratable acidity was also determined according to (Aguayo et al., 2013). Ten grams of homogenized pulp were diluted in $50 \mathrm{~mL}$ of distilled water and titrated with standardized $0.1 \mathrm{~N} \mathrm{NaOH}$ to $\mathrm{pH}$ 8.1. The results are expressed in grams of citric acid per $100 \mathrm{~g}$ of pulp.

\subsubsection{Lycopene content}

Lycopene content was determined according to Nagata and Yamashita (1992). Tomato pulp samples were ground in liquid $N_{2}$, transferred $2 \mathrm{~g}$ to a 50 -mL Falcon tube, combined with $10 \mathrm{~mL}$ of acetone:hexane (4:6) extraction solution, and homogenized by vortexing (Phoenix Luferco, AP 56, Araraquara, Brazil). Following homogenization, $4 \mathrm{~mL}$ of the liquid phase was transferred to a quartz cuvette, and the absorption was read at $663 \mathrm{~nm}$ (chlorophyll a), $645 \mathrm{~nm}$ (chlorophyll b), $505 \mathrm{~nm}$ (lycopene), and $453 \mathrm{~nm}$ ( $\beta$-carotene) in a UV-vis spectrophotometer (Femto, 700 plus, São Paulo, Brazil). Lycopene content was calculated using the following equation:

Lycopene $=-0.0458 \mathrm{~A}_{663}+0.204 \mathrm{~A}_{645}+0.372 \mathrm{~A}_{505}-0.0806 \mathrm{~A}_{453}$

in which $\mathrm{A}_{\mathrm{Xxx}}=$ absorbance at the specified wavelength. The results are expressed as $\mathrm{mg} 100 \mathrm{~g}^{-1}$ pulp.

\subsection{Statistical analysis}

A randomized complete block experimental design (RCBD) was used, with 5 treatments and 3 replicates, with each pressure representing one treatment and each collection representing one block. The data were subjected to analysis of variance (ANOVA) using the software Infostat 2012 (Universidad Nacional de Córdoba, Argentina). Averages were compared using Tukey's test at $\mathrm{p} \leq 0.05$. When significant differences were observed, a regression analysis was performed.

\section{Results and discussion}

\subsection{Weight loss}

A functional relationship was observed between the level of pressure applied and tomato weight loss following each period of HP application $(2,4$ and $6 \mathrm{~d})$ and $\mathrm{HP}+2 \mathrm{~d}(4+2$ and $6+2 \mathrm{~d})($ Fig. $2 \mathrm{~A}$ and B). For both storage conditions, tomato weight loss was observed to decrease with increasing pressure. The largest weight losses were observed for tomatoes subjected to $100 \mathrm{kPa}$ (Control) or $200 \mathrm{kPa} \mathrm{HP}$ for $6 \mathrm{~d}$ (average $1.71 \%$ ) followed by $2 \mathrm{~d}$ of storage (average $2.50 \%$ ) (Fig. 2A and B). Weight loss was lower for treatment with 400, 600 and $800 \mathrm{kPa}$ than for the control and $200 \mathrm{kPa}$ treatments. Weight loss increased with increasing HP duration, especially when lower pressures were applied; weight loss in the samples that received the control treatment averaged $1.52 \%$ after $6 \mathrm{~d}$. The increase in weight loss with time was significantly attenuated in tomatoes treated with higher pressures $(400,600$ and $800 \mathrm{kPa})$. Tomatoes subjected to $800 \mathrm{kPa}$ 

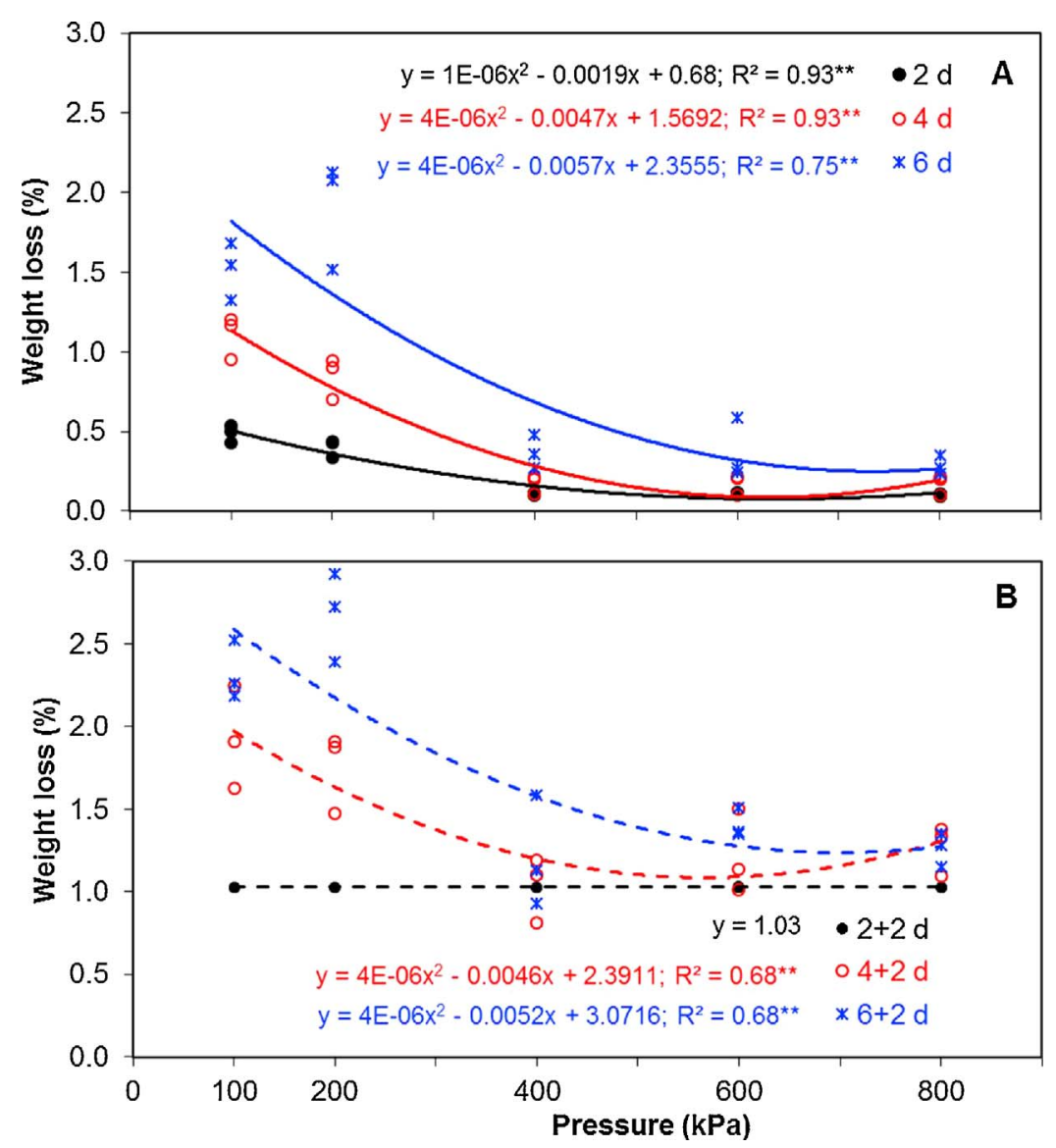

Fig. 2. Relationship between weight loss in the tomato cultivar 'Débora' and application of hyperbaric pressure for 2,4 or $6 \mathrm{~d}$ at $23^{\circ} \mathrm{C}$ and $95 \% \mathrm{RH}$ (A) followed by $2 \mathrm{~d}$ under ambient conditions $\left(23^{\circ} \mathrm{C}, 50 \% \mathrm{RH}\right.$ and $100 \mathrm{kPa}$ ) (B). * significant at $\mathrm{p}<0.05$; ** significant at $\mathrm{p}<0.01$. pressure for $6 \mathrm{~d}$ presented weight loss of only $0.29 \%$; i.e. (Fig. 2A). A similar trend of tomato weight loss was observed after the period of HP application following an additional $2 \mathrm{~d}$ of storage under ambient conditions $(4+2$ and $6+2$ ) (Fig. 2 B).

The present results indicate that changing the atmospheric pressure at which the produce is stored, especially when the pressure is increased to 400,600 or $800 \mathrm{kPa}$, efficiently decreased weight loss in the tomato cultivar 'Débora'.

Tomatoes are very susceptible to rapid water loss, which causes weight loss; this is due to their thin skin, which offers very little resistance to mass transfer (García et al., 2014). Weight losses of up to $10 \%$ were observed in cherry tomatoes after $25 \mathrm{~d}$ of storage at $5{ }^{\circ} \mathrm{C}$ and 80-85\% RH (Fagundes et al., 2015a). Weight losses of 5-6\% negatively affect tomato appearance, texture and commercial weight (Kantola and Helén, 2001).

Atmospheric pressure is one of the main factors affecting air vapor pressure. The rate of water loss from fresh vegetables is mainly determined by the difference between the ambient pressure and the intercellular vapor pressure, with smaller pressure differences resulting in smaller water losses (Kader, 2002). This would explain the higher weight losses observed in tomatoes that received the control treatment compared to those that received HP treatment.

\subsection{Color}

A significant linear relationship was observed $(\mathrm{p}<0.01)$ for the pressure level with tomato lightness and hue angle following application of HP (2, 4 or $6 \mathrm{~d})$ and HP $+2 \mathrm{~d}(2+2,4+2$ and $6+2)$ (Fig. 3A-D). During the entire storage period, the tomatoes that received the control treatment presented lower lightness and Hue angle than pressurized tomatoes. Tomato chromaticity was not affected by hyperbaric pressure, presenting an average value of 31.07 during storage.
Skin color is the most important external characteristic for assessing tomato ripeness (Batu, 2004; Kim et al., 2015). Low lightness and hue angle indicate redder and darker color, i.e., more ripe tomatoes. Chromaticity is not a good indicator of tomato ripeness because tomatoes present various colors simultaneously during ripening due to chlorophyll degradation and carotenoid synthesis (López Camelo and Gómez, 2004). The present results indicate that hyperbaric pressure inhibited the development of red color in the tomato cultivar 'Débora' (Fig. 4).

\subsection{Firmness}

A linear relationship was observed between pressure and tomato firmness following application of HP (4 and $6 \mathrm{~d})$ and HP $+2 \mathrm{~d}(4+2$ and $6+2$ ) (Fig. 5A and B). On the second day of HP application, no functional relationship between tomato firmness and the level of applied pressure was observed ( $p>0.05$ ). However, the tomatoes presented an average $27 \%$ decrease in firmness compared to the initial values (35.21 $\pm 1.45 \mathrm{~N})$ (Fig. $5 \mathrm{~A})$. After $4 \mathrm{~d}$, the tomatoes treated with $800 \mathrm{kPa}$ presented approximately $61 \%$ higher firmness than control tomatoes $(100 \mathrm{kPa})$. Similar changes were observed on day 6 , with fruit subjected to 600 or $800 \mathrm{kPa}$ presenting higher firmness (average $17.60 \mathrm{~N}$ ) than those subjected to the control and $200 \mathrm{kPa}$ treatments (8.15 and $8.68 \mathrm{~N}$, respectively).

The maintenance of fruit and vegetable firmness primarily depends on factors such as tissue turgidity and cell wall degradation, both of which are triggered by ripening (Fagundes et al., 2015a). In the present study, differences in tomato firmness were observed to be related to both factors; firmer tomatoes presented lower weight loss (higher turgidity) (Fig. 2) and less intense red color (Fig. 4). In cherry tomatoes with an antifungal coating stored for $21 \mathrm{~d}$ at $5{ }^{\circ} \mathrm{C}$ and $90-95 \% \mathrm{RH}$, fruit presenting lower water loss were observed to present higher firmness 

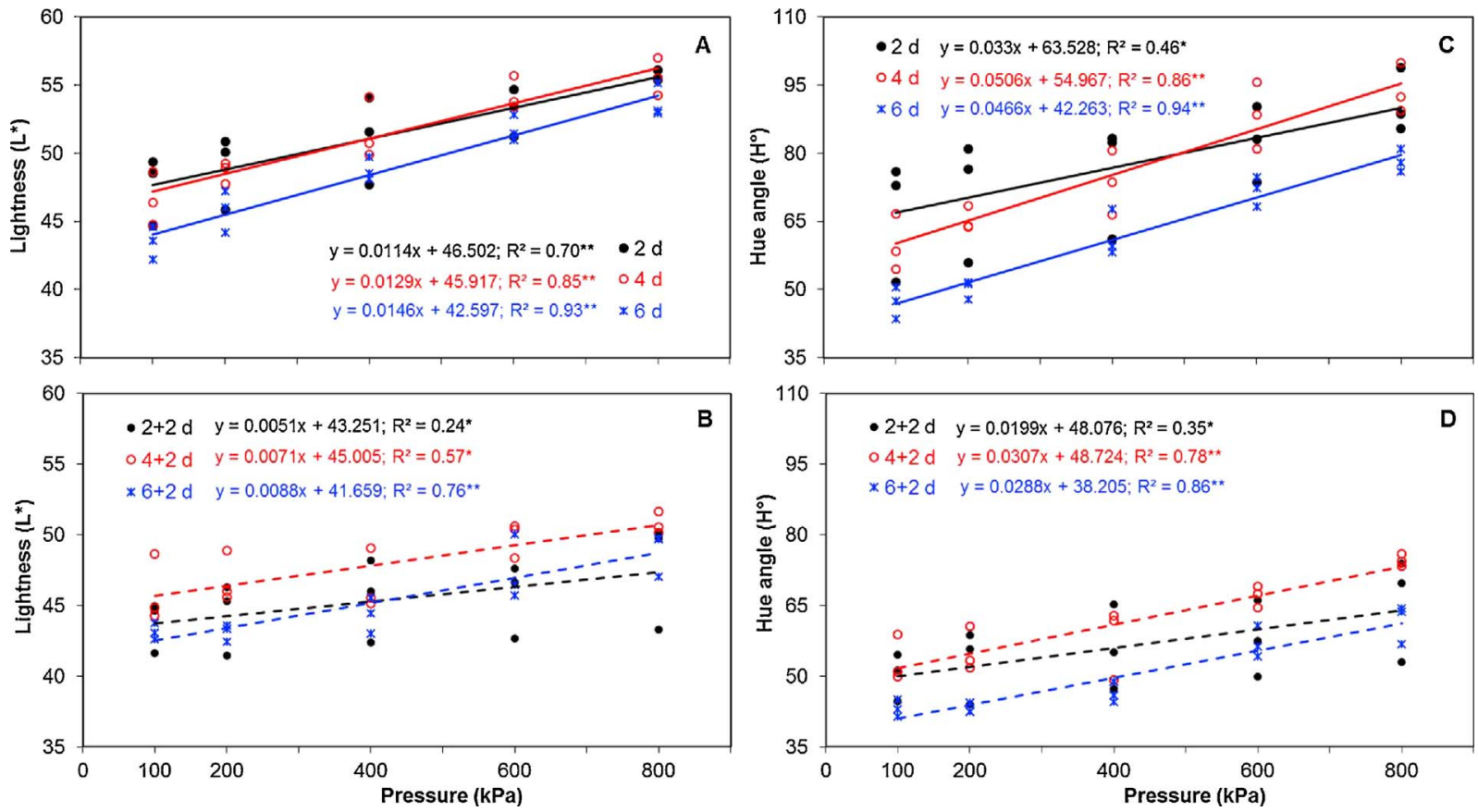

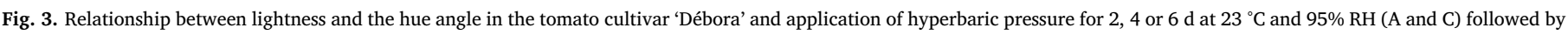
$2 \mathrm{~d}$ under ambient conditions $\left(23^{\circ} \mathrm{C}, 50 \% \mathrm{RH}\right.$ and $100 \mathrm{kPa}$ ) (B and $\left.\mathrm{D}\right)$. * significant at $\mathrm{p}<0.05$; ** significant at $\mathrm{p}<0.01$.

(Fagundes et al., 2015b). Similar results were observed for blueberries stored for 3 weeks at $4{ }^{\circ} \mathrm{C}$; in that study, post-harvest water loss was the main factor determining loss of fruit firmness (Paniagua et al., 2013).

A similar trend was observed for the relationship between tomato firmness and the level of applied pressure following HP application and storage (HP $+2 \mathrm{~d}$ ) (Fig. 5B). A functional relationship between tomato firmness and applied pressure was not observed for the $2+2$ samples ( $p>0.05$ ), whereas a linear relationship between the two variables was observed for samples in the $4+2$ and $6+2$ treatment groups.

Firmness is an essential factor in determining tomato quality because it affects the susceptibility of the fruit to physical damage and consequently its suitability for commercialization. Studies have shown that tomatoes must display a minimum firmness of $6.86 \mathrm{~N}$ to be sold fresh (Gormley and Egan, 1978). 'Débora' tomatoes subjected to pressures of $200,400,600$ and $800 \mathrm{kPa}$ at $23{ }^{\circ} \mathrm{C}$ therefore presented more than sufficient firmness to be sold fresh $8 \mathrm{~d}$ after harvest ( $6 \mathrm{~d}$ of hyperbaric treatment $+2 \mathrm{~d}$ at $100 \mathrm{kPa}$ ), whereas control tomatoes only presented firmness suitable for being sold fresh during the $6 \mathrm{~d}$ of hyperbaric treatment (Fig. 5B).

\subsection{Respiration rate $(R R)$}

For the first $15 \mathrm{~h}$ of storage, the applied treatments affected the tomato respiration rate (RR) differently (Fig. 6). The average RR was $24 \mathrm{mg} \mathrm{CO}_{2} \mathrm{~kg}^{-1} \mathrm{~h}^{-1}$ for fruit stored at 100 and $200 \mathrm{kPa}$, whereas fruit subjected to higher pressures $(400,600$ and $800 \mathrm{kPa})$ presented an initial average RR of $14 \mathrm{mg} \mathrm{CO} \mathrm{kg}^{-1} \mathrm{~h}^{-1}$, similar to that observed in fruit treated with pressures of 100 and $200 \mathrm{kPa}$ after $15 \mathrm{~h}$ of treatment.

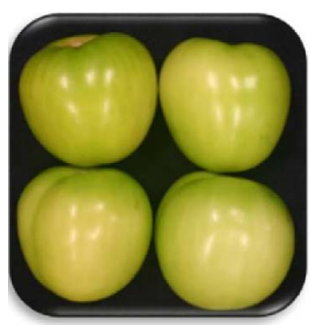

A

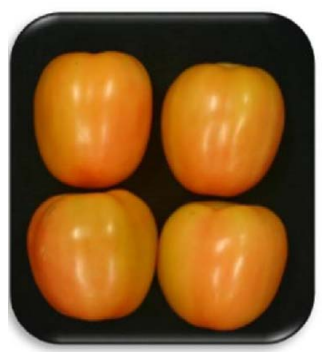

D

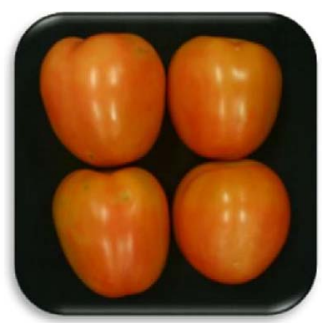

B

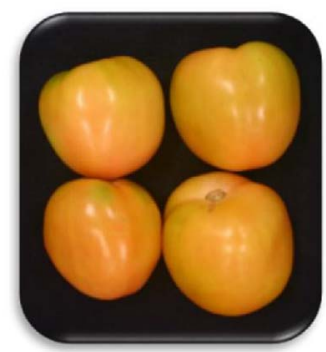

$\mathbf{E}$

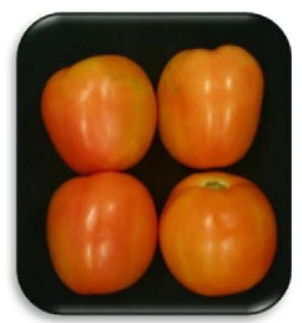

C

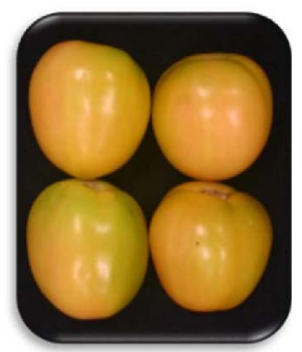

F
Fig. 4. Appearance of the tomato cultivar 'Débora' before of storage (A) and after storage for $4 \mathrm{~d}$ at pressures of $100 \mathrm{kPa}(\mathrm{B}), 200 \mathrm{kPa}(\mathrm{C}), 400 \mathrm{kPa}$ (D), $600 \mathrm{kPa}(\mathrm{E})$ or $800 \mathrm{kPa}(\mathrm{F})$ at $23^{\circ} \mathrm{C}$ and $95 \% \mathrm{RH}$. 

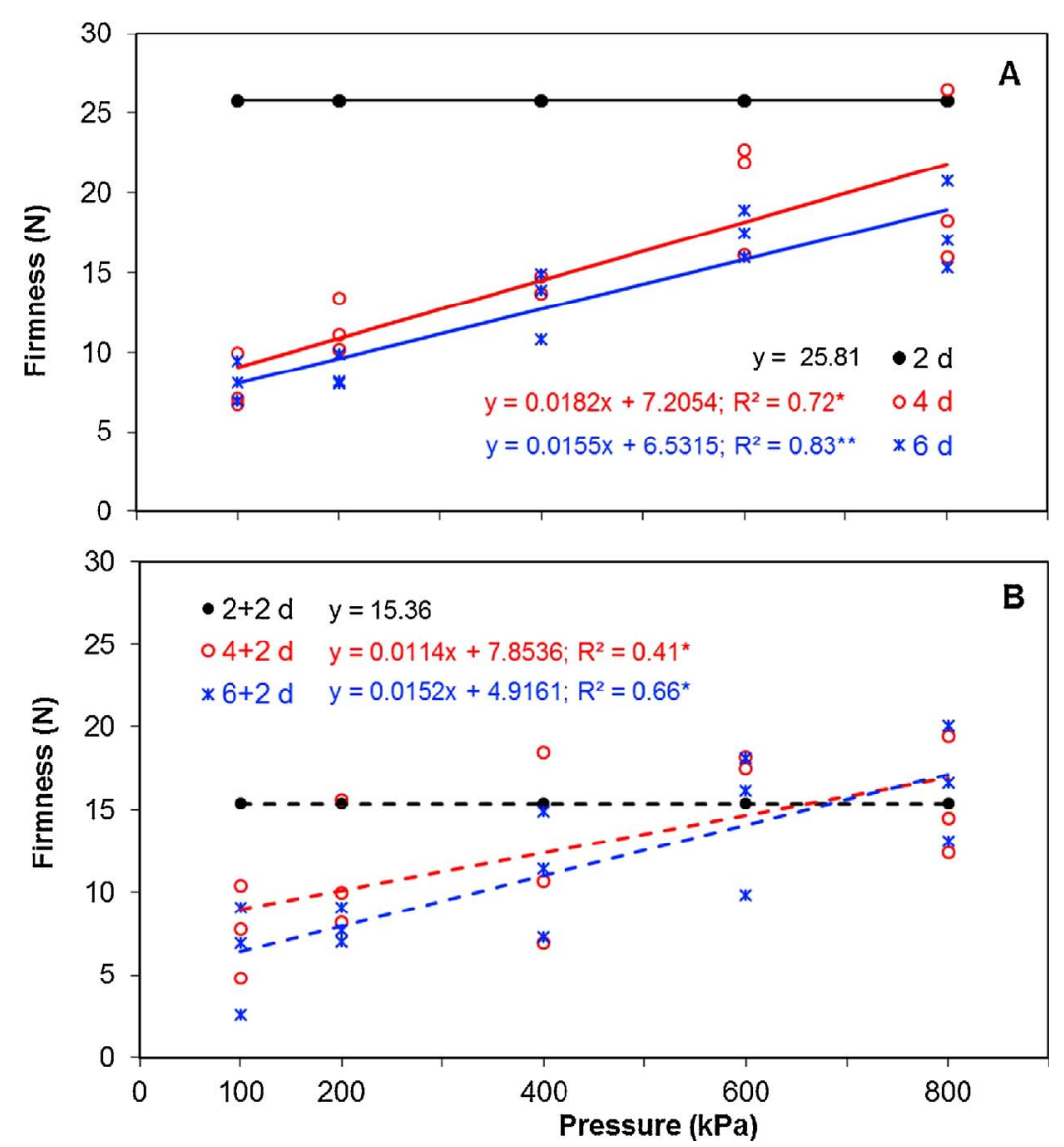

Fig. 5. Relationship between firmness in the tomato cultivar 'Débora' and application of hyperbaric pressure for 2,4 or $6 \mathrm{~d}$ at $23{ }^{\circ} \mathrm{C}$ and $95 \% \mathrm{RH}$ (A) followed by $2 \mathrm{~d}$ under ambient conditions $\left(23^{\circ} \mathrm{C}, 50 \% \mathrm{RH}\right.$ and $\left.100 \mathrm{kPa}\right)$ (B). * significant at $\mathrm{p}<0.05 ; * *$ significant at $\mathrm{p}<0.01$.
This may be attributed to $\mathrm{CO}_{2}$ dilution in the vessels containing the fruit and $\mathrm{CO}_{2}$ solubilization within the fruit resulting from the increased partial pressure of atmospheric gases inside the hyperbaric chamber (Goyette et al., 2012a). The $\mathrm{CO}_{2}$ resulting from tomato respiration was probably solubilized in the tomato pulp until it equaled the atmospheric $\mathrm{CO}_{2}$ partial pressure and subsequently diluted within the hyperbaric chamber, causing an increase in the $\mathrm{CO}_{2}$ partial pressure of the air surrounding the produce and consequently of the $\mathrm{CO}_{2}$ concentration inside the chamber. This dilution and solubilization process is continuous and only stabilizes when the amount of $\mathrm{CO}_{2}$ leaving the chamber and entering the gas analyzer becomes equal to that generated by tomato respiration (Liplap et al., 2014).

After $15 \mathrm{~h}$ of treatment, the RRs of the tomatoes in all the experimental groups gradually increased, reaching equilibrium after approximately $60 \mathrm{~h}$. From that time until the end of the experiment, higher RRs were observed in tomatoes subjected to 200 or $400 \mathrm{kPa}$ pressure than in those subjected to 600 or $800 \mathrm{kPa}$ pressure or to the control treatment. No decreases in RR relative to the control were observed in tomatoes that received HP treatment, indicating that HP did not efficiently decrease the RR of the tomato cultivar 'Débora'.

Similar results were reported for tomatoes subjected to different pressures at $20^{\circ} \mathrm{C}$ (Liplap et al., 2013a). However, tomatoes stored under HP for 5, 10 and $15 \mathrm{~d}$ at $13{ }^{\circ} \mathrm{C}$ showed decreases in RR of 22, 20, 16 and $11 \%$ when stored at pressures of $900,700,500$ and $300 \mathrm{kPa}$, respectively (Goyette et al., 2012b).

The present results, together with the cited previous reports, suggest

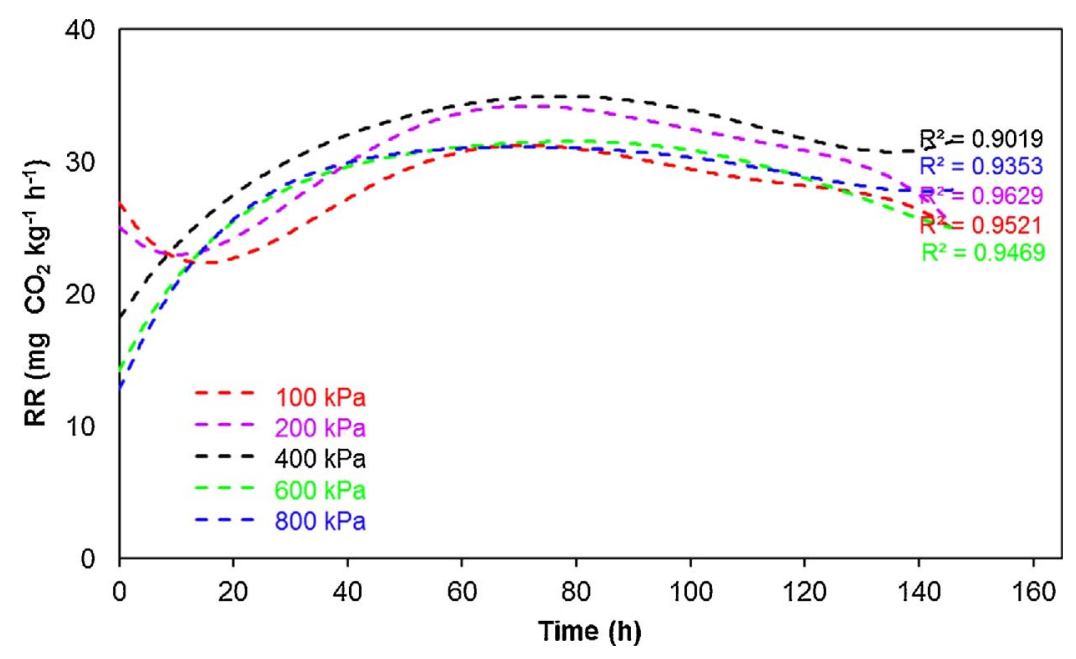

Fig. 6. Respiration rate in real time of the tomato cultivar 'Débora' subjected to different pressures for $6 \mathrm{~d}$ at $23{ }^{\circ} \mathrm{C}$ and $95 \% \mathrm{RH}$. 


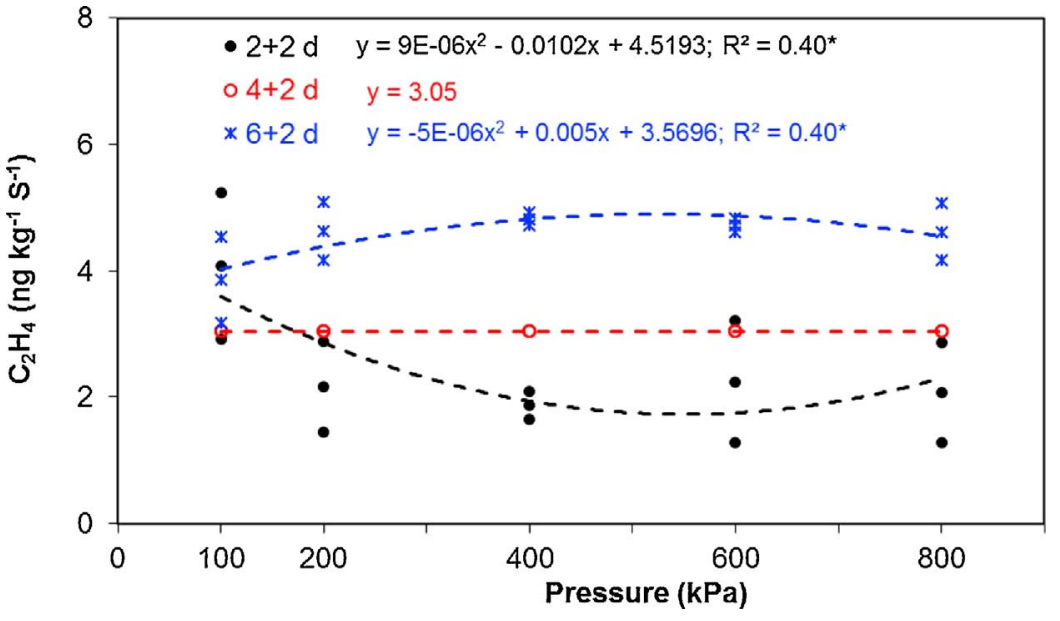

Fig. 7. Relationship between ethylene production in the tomato cultivar 'Débora' and application of hyperbaric pressure for 2,4 or $6 \mathrm{~d}$ at $23^{\circ} \mathrm{C}$ and $95 \% \mathrm{RH}$, followed by $2 \mathrm{~d}$ under ambient conditions at $23{ }^{\circ} \mathrm{C}, 50 \% \mathrm{RH}$ and $100 \mathrm{kPa}$. * significant at $\mathrm{p}<0.05 ; * *$ significant at $\mathrm{p}<0.01$. a possible synergism between refrigeration temperature and hyperbaric pressure in decreasing RRs. However, there are few reports of the effect of hyperbaric pressure on fruit and vegetable metabolism, and further research is needed.

\subsection{Ethylene production}

A significant functional relationship between ethylene production in the tomato cultivar 'Débora' and the level of pressure applied was observed for treatments $2+2$ and $6+2$ ( $<<0.05$; Fig. 7), but not for treatment $4+2(\mathrm{p}>0.05)$; with the latter treatment, an average ethylene production of $3 \mathrm{ng} \mathrm{kg}^{-1} \mathrm{~S}^{-1}$ was observed. For treatment $2+2$, ethylene production was higher in the control $\left(4 \mathrm{ng} \mathrm{kg}^{-1} \mathrm{~S}^{-1}\right)$ than in the pressurized tomatoes, whereas for treatment $6+2$, it was slightly higher for tomatoes subjected to 400,600 and $800 \mathrm{kPa}$ than for control tomatoes.

Ethylene is the main hormone that triggers and regulates the ripening process in climacteric fruit (Zhu et al., 2015). Most tomato cultivars present climacteric behavior; therefore, any significant increase in $\mathrm{RR}$ and ethylene production stimulates fruit ripening, increases losses, and decreases the post-harvest quality of stored produce (Guo et al., 2014).

The present results indicate that control tomatoes and pressurized tomatoes reached the climacteric stage on day $2+2$ and on day $6+2$, respectively. This may indicate delayed ripening of pressurized fruit compared to control fruit since, in addition to reaching the climacteric stage later (Fig. 6), the pressurized fruit also presented less intense red color (Fig. 3) and greater firmness (Fig. 5).

\subsection{Total soluble solids (TSS)}

After $6 \mathrm{~d}$ of HP, the TSS content of tomatoes subjected to the $800 \mathrm{kPa}$ pressure was $13 \%$ lower than that of control tomatoes (Fig. 8), whereas after treatment HP $+2 \mathrm{~d}$, no functional relationship was observed between tomato TSS content and the pressure applied ( $p>0.05$ ). The average TSS contents of the tomatoes subjected to HP $+2 \mathrm{~d}$ treatment were $4.38,4.67$ and 4.91 for treatments $2+2,4+2$ and $6+2$, respectively.

The lower TSS contents observed for tomatoes subjected to hyperbaric pressure indicates that hyperbaric pressure slows the conversion of complex carbohydrates to simple sugars (Liplap et al., 2013a). After $2 \mathrm{~d}$ under ambient conditions, no significant differences in tomato TSS content were observed between tomatoes subjected to hyperbaric pressure and control tomatoes, regardless of the duration of the HP treatment. Given that the increase in TSS content in post-harvest tomatoes is related to the progress of the ripening process, this result indicates that the pressure level affected tomato TSS content during hyperbaric treatment by delaying ripening but that the tomatoes ripened normally after being transferred to ambient conditions.

The amount and type of sugars present are important factors for the post-harvest quality of tomatoes, affecting their flavor and general quality for both fresh commercialization and industrial processing, and depend on interactions between genetic, agronomic, climatic and postharvest handling factors (Beckles, 2012).

\subsection{Titratable acidity}

The titratable acidity (TA) of the tomato cultivar 'Débora' was not significantly affected ( $\mathrm{p}>0.05$ ) by hyperbaric pressure in either of the two tested conditions (HP and HP $+2 \mathrm{~d}$ ) (Table 2). The average TA was $14 \%$ lower on the last day of the evaluation $(6+2 ; 0.25 \mathrm{~g}$ citric acid $100 \mathrm{~g}^{-1}$ pulp) than the initial TA $\left(0.29 \mathrm{~g}\right.$ citric acid $100 \mathrm{~g}^{-1}$ pulp).

Tomato acidity reflects the amount of organic acid present in fruit (Ferreira et al., 2010). Decreased tomato acidity during the post-harvest period is related to higher consumption of organic acids in respiration and/or conversion of acids into sugars during glycogenesis, which is associated with fruit ripening (Anthon et al., 2011). The acidity values observed in the present study were related to the observed RRs; i.e., HP treatment resulted in no advantage in terms of RR relative to the control, and a similar trend was observed for acidity.

\subsection{TSS:TA ratio}

The TSS:TA ratio of the tomato cultivar 'Débora' was not significantly affected by hyperbaric pressure ( $\mathrm{p}>0.05$; Table 2 ). This was due to the small observed variation in TSS content and the absence of significant differences in TA. The average TSS:TA for all treatments was 15.30 on day 2 and 19.81 following storage under ambient conditions $(6+2)$.

Sugars and organic acids account for most of the total dry matter content of tomato fruit (Malundo et al., 1995). Their ratio determines the balance between fruit sugars and acids and affects consumer acceptance of the product. Low sugar and high acid content result in acidic flavor, whereas the opposite results in a sweeter flavor. When both sugars and acids are low, the result is a tasteless tomato (Schouten et al., 2016). This relationship is also attributed to the maturation of some vegetables, as low TSS:TA indicates the predominance of acids over sugars, a characteristic of immature fruit.

TSS:TA tended to increase during storage for all tested treatments due to fruit ripening. A minimum TSS:TA of 12.5 is considered desirable to produce tomatoes with good flavor for fresh consumption (Beckles, 2012). In the present study, all treatments presented TSS:TA greater than 12.5, indicating an excellent sugar-acid balance resulting in goodquality tomatoes. 


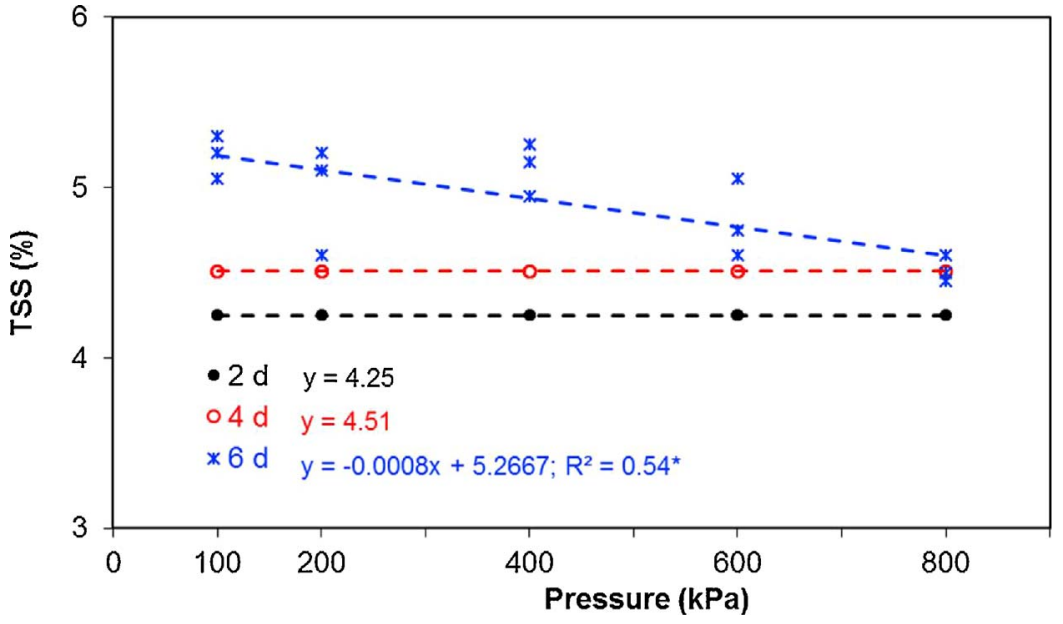

Fig. 8. Relationship between total soluble solids in the tomato cultivar 'Débora' and application of hyperbaric pressure for 2,4 or $6 \mathrm{~d}$ at $23^{\circ} \mathrm{C}$ and $95 \%$ RH. * significant at $\mathrm{p}<0.05$; ** significant at $\mathrm{p}<0.01$.

\subsection{Lycopene content}

Various equations were fitted to the relationship between tomato lycopene content and applied pressure following HP and HP $+2 \mathrm{~d}$. With the exception of the day $2+2$ experimental group, tomatoes subjected to hyperbaric pressure presented lower lycopene content than control tomatoes (Fig. 9A and B). On days 4 and 6, a negative linear relationship ( $\mathrm{p}<0.01$ ) was observed between tomato lycopene content and the applied pressure; tomatoes subjected to the highest tested pressure $(800 \mathrm{kPa})$ presented lycopene contents that were $66 \%$ and $57 \%$ lower than those of control tomatoes on days 4 and 6 , respectively (Fig. 9A). This indicates that hyperbaric pressure slowed maturation, the period during which tomato lycopene content increases, even when the tomatoes were stored at optimal temperature for lycopene synthesis $\left(16-26^{\circ} \mathrm{C}\right.$ ) (Türk et al., 1994). A similar trend was observed in the HP $+2 \mathrm{~d}(4+2$ and $6+2)$ and HP treatment groups subjected to $800 \mathrm{kPa}$ pressure, in which the lycopene contents were $39 \%$ and $30 \%$ lower, respectively, than those of the controls (Fig. 9B).

Tomato maturation is associated with changes in fruit color from green to red. These changes result from chlorophyll degradation and, especially, carotenoid synthesis (lycopene and $\beta$-carotene) (Smita et al., 2013; Su et al., 2015). Tomato carotenoid content can increase 10- to 14-fold during ripening (Tohge et al., 2014). Lycopene is considered the most abundant carotenoid in tomatoes and is thought to be the compound responsible for the red color of ripe tomatoes (Brandt et al., 2006; Del Giudice et al., 2015).

Tomatoes stored at $13{ }^{\circ} \mathrm{C}$ and subjected to different levels of hyperbaric pressure for 5,10 and $15 \mathrm{~d}$ showed delayed lycopene synthesis compared to control fruit. However, when the fruit were removed from the hyperbaric conditions and allowed to complete the ripening process at $20{ }^{\circ} \mathrm{C}$ for $12 \mathrm{~d}$, a significant increase in lycopene concentration was observed in treated fruit relative to fruit stored at ambient pressure (Goyette, 2010). Similar results were reported by Liplap et al. (2013b), for tomatoes stored under hyperbaric conditions for $4 \mathrm{~d}$ at $20^{\circ} \mathrm{C}$ followed by storage at ambient pressure for $10 \mathrm{~d}$ to complete ripening.

In the present study, no increase in lycopene content was observed in tomatoes subjected to hyperbaric pressure treatment. Two days under ambient conditions was likely insufficient time for the full color change to develop, as reported by Goyette (2010) and Liplap et al. (2013b). The observed lack of increase in lycopene content could also be due to the influence of pre-harvest factors such as the cultivar used, the production temperature, the amount of light, the type of soil and nutritional factors (Mattiuz, 2007). The response of tomatoes to hyperbaric pressure may therefore be related to a specific stress generated by pressure that affects biological responses such as carotenoid synthesis.

Table 2

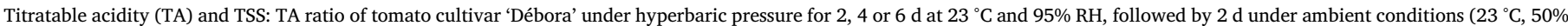
$\mathrm{RH}$ and $100 \mathrm{kPa}$ ).

\begin{tabular}{|c|c|c|c|c|c|c|c|}
\hline \multirow[t]{3}{*}{ Parameter } & \multirow[t]{3}{*}{ Treatment } & \multicolumn{6}{|c|}{ Days of storage } \\
\hline & & \multicolumn{3}{|l|}{ Pressure } & \multicolumn{3}{|c|}{ Pressure + Ambient } \\
\hline & & 2 & 4 & 6 & $2+2$ & $4+2$ & $6+2$ \\
\hline \multirow[t]{6}{*}{ AT (g $100 g^{-1}$ pulp) } & $100 \mathrm{kPa}$ & $0.30 \mathrm{Aa}^{*}$ & $0.31 \mathrm{Aa}$ & $0.26 \mathrm{Aa}$ & $0.26 \mathrm{Aa}$ & $0.26 \mathrm{Aa}$ & $0.25 \mathrm{Aa}$ \\
\hline & $200 \mathrm{kPa}$ & $0.29 \mathrm{Aa}$ & $0.28 \mathrm{Aa}$ & $0.24 \mathrm{Aa}$ & $0.26 \mathrm{Aa}$ & $0.24 \mathrm{Aa}$ & $0.25 \mathrm{Aa}$ \\
\hline & $400 \mathrm{kPa}$ & $0.29 \mathrm{Aa}$ & $0.26 \mathrm{Aa}$ & $0.26 \mathrm{Aa}$ & $0.25 \mathrm{Aa}$ & $0.25 \mathrm{Aa}$ & $0.25 \mathrm{Aa}$ \\
\hline & $600 \mathrm{kPa}$ & $0.27 \mathrm{Aa}$ & $0.26 \mathrm{Aa}$ & $0.25 \mathrm{Aa}$ & $0.25 \mathrm{Aa}$ & $0.24 \mathrm{Aa}$ & $0.23 \mathrm{Aa}$ \\
\hline & $800 \mathrm{kPa}$ & $0.25 \mathrm{Aa}$ & $0.25 \mathrm{Aa}$ & $0.25 \mathrm{Aa}$ & $0.24 \mathrm{Aa}$ & $0.24 \mathrm{Aa}$ & $0.25 \mathrm{Aa}$ \\
\hline & C.V (\%) & 10.70 & 9.29 & 7.36 & 6.98 & 7.14 & 9.72 \\
\hline \multirow[t]{6}{*}{ TSS:AT ratio } & $100 \mathrm{kPa}$ & $14.60 \mathrm{Ab}$ & $15.06 \mathrm{Ab}$ & $20.00 \mathrm{Aa}$ & $17.12 \mathrm{Ab}$ & $18.80 \mathrm{Aab}$ & $19.80 \mathrm{Aa}$ \\
\hline & $200 \mathrm{kPa}$ & $14.72 \mathrm{Aa}$ & $16.79 \mathrm{Aa}$ & $20.71 \mathrm{Aa}$ & $17.19 \mathrm{Aa}$ & $19.29 \mathrm{Aa}$ & $19.32 \mathrm{Aa}$ \\
\hline & $400 \mathrm{kPa}$ & $15.00 \mathrm{Ab}$ & 17.42 Aab & $19.88 \mathrm{Aa}$ & $17.80 \mathrm{Aa}$ & $18.82 \mathrm{Aa}$ & $19.48 \mathrm{Aa}$ \\
\hline & $600 \mathrm{kPa}$ & $15.19 \mathrm{Aa}$ & $16.54 \mathrm{Aa}$ & $19.32 \mathrm{Aa}$ & $17.28 \mathrm{Aa}$ & $19.22 \mathrm{Aa}$ & $20.87 \mathrm{Aa}$ \\
\hline & $800 \mathrm{kPa}$ & $16.60 \mathrm{Aa}$ & $17.88 \mathrm{Aa}$ & $18.12 \mathrm{Aa}$ & $17.58 \mathrm{Aa}$ & $18.89 \mathrm{Aa}$ & $20.40 \mathrm{Aa}$ \\
\hline & C.V (\%) & 8.20 & 6.80 & 6.58 & 5.27 & 4.42 & 9.98 \\
\hline
\end{tabular}

* For the different parameters (TA and TSS:TA ratio) and storage conditions (pressure and pressure + ambient), values within a column followed by the same upper case letter and values within a row followed by the same lower case letter are not significantly different according to Tukey's test $(p>0.05)$. 


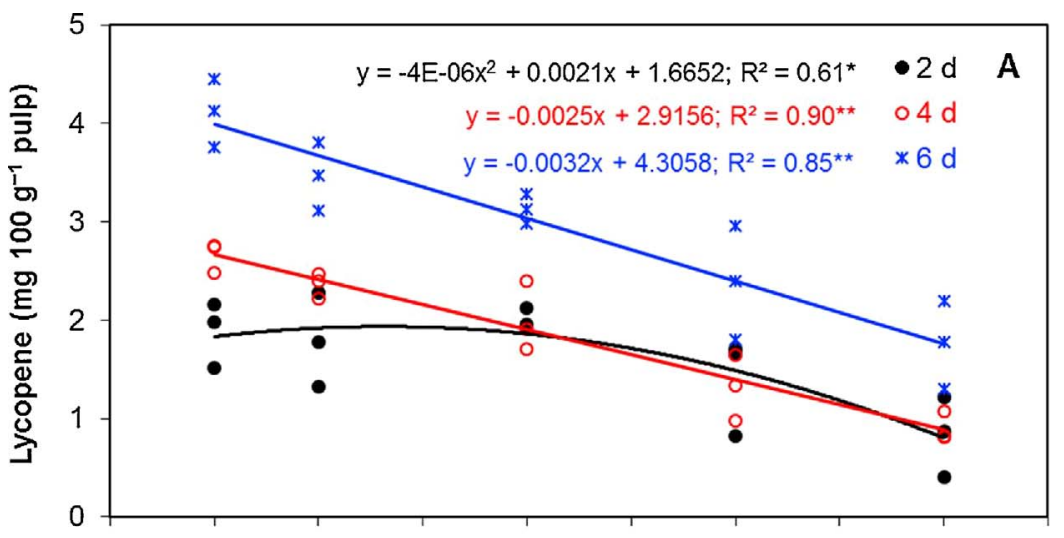

Fig. 9. Relationship between lycopene content in the tomato cultivar 'Débora' and application of hyperbaric pressure for 2,4 or $6 \mathrm{~d}$ at $23^{\circ} \mathrm{C}$ and $95 \% \mathrm{RH}$ (A) followed by $2 \mathrm{~d}$ under ambient conditions $\left(23^{\circ} \mathrm{C}, 50 \% \mathrm{RH}\right.$ and $100 \mathrm{kPa})(\mathrm{B}) . *$ significant at $\mathrm{p}<0.05 ; * *$ significant at $\mathrm{p}<0.01$.

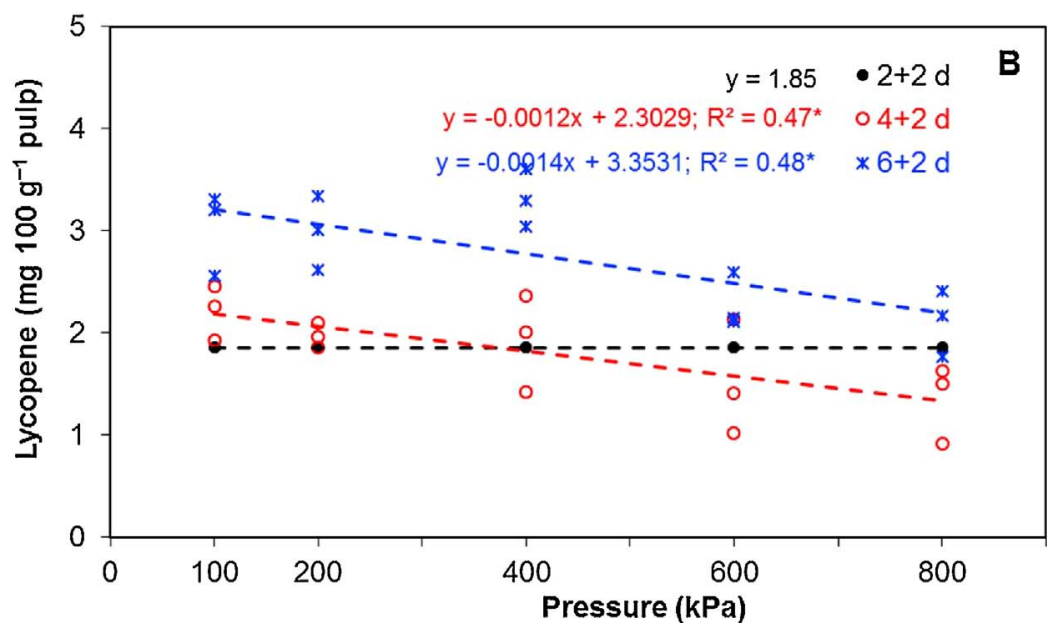

\section{Conclusions}

Application of hyperbaric pressure of $200-800 \mathrm{kPa}$ to the tomato cultivar 'Débora' at $23^{\circ} \mathrm{C}$ for 2,4 or $6 \mathrm{~d}$ followed by $2 \mathrm{~d}$ at ambient pressure and temperature $\left(100 \mathrm{kPa}\right.$ and $\left.23^{\circ} \mathrm{C}\right)$ did not result in decreased RR compared to the control. However, pressures of 400, 600 and $800 \mathrm{kPa}$ resulted in delayed climacteric stage, indicated by lower tomato ethylene production, lower weight loss, greater firmness, less intense red color, and lower lycopene synthesis, compared to control tomatoes. In addition, application of hyperbaric pressure in this range did not affect tomato flavor characteristics (total soluble solids, acidity or TSS:TA ratio); these were always similar to those of control tomatoes.

\section{Acknowledgments}

The authors wish to thank the Foundation for Research Support of the State of São Paulo (FAPESP) for financial support (Process n 2015/ 07152-6) and the Program PAEDEX-UNESP for the Ph.D. scholarship granted to the first author.

\section{References}

Aguayo, E., Escalona, V., Silveira, A.C., Artés, F., 2013. Quality of tomato slices disinfected with ozonated water. Food Sci. Technol. Int. 20 (3), 227-235.

Anthon, G.E., LeStrange, M., Barrett, D.M., 2011. Changes in pH, acids, sugars and other quality parameters during extended vine holding of ripe processing tomatoes. J. Sci. Food Agric. 91, 1175-1181.

Azabou, S., Abid, Y., Sebii, H., Felfoul, I., Gargouri, A., Attia, H., 2016. Potential of the solid-state fermentation of tomato by products by Fusarium solani pisi for enzymatic extraction of lycopene. Food Sci. Technol. 68, 280-287.

Baba, T., Ikeda, F., 2003. Use of high-pressure treatment to prolong the postharvest life of mume fruit (Prunus mume). Acta Hortic. 628, 373-377.

Batu, A., 2004. Determination of acceptable firmness and colour values of tomatoes. J. Food Eng. 61 (3), 471-475.
Beckles, D.M., 2012. Factors affecting the postharvest soluble solids and sugar content of tomato (Solanum lycopersicum L.) fruit. Postharvest Biol. Technol. 63 (1), 129-140.

Brandt, S., Pék, Z., Barna, É., Lugasi, A., Helyes, L., 2006. Lycopene content and colour of ripening tomatoes as affected by environmental conditions. J. Sci. Food Agric. 86 (4), $568-572$.

Del Giudice, R., Raiola, A., Tenore, G.C., Frusciante, L., Barone, A., Monti, D.M., Rigano, M.M., 2015. Antioxidant bioactive compounds in tomato fruits at different ripening stages and their effects on normal and cancer cells. J. Funct. Foods 18, 83-94.

Fagundes, C., Moraes, K., Perez-Gago, M.B., Palou, L., Maraschin, M., Monteiro, A.R., 2015a. Effect of active modified atmosphere and cold storage on the postharvest quality of cherry tomatoes. Postharvest Biol. Technol. 109, 73-81.

Fagundes, C., Palou, L., Monteiro, A.R., Pérez-Gago, M.B., 2015b. Hydroxypropyl methylcellulose-beeswax edible coatings formulated with antifungal food additives to reduce alternaria black spot and maintain postharvest quality of cold-stored cherry tomatoes. Sci. Hortic. 193, 249-257.

Ferreira, S.M.R., Freitas, R.J.S.D., Karkle, E.N.L., Quadros, D.A.D., Tullio, L.T., Lima, J.J.D., 2010. Quality of tomatoes cultivated in the organic and conventional cropping systems. Ciênc. Tecnol. Aliment. Campinas 30 (1), 224-230.

García, M., Casariego, A., Díaz, R., Roblejo, L., 2014. Effect of edible chitosan/zeolite coating on tomatoes quality during refrigerated storage. Emir. J. Food Agric. 26 (3), $238-246$.

Gormley, R., Egan, S., 1978. Firmness and colour of the fruit of some tomato cultivars from various sources during storage. J. Sci. Food Agric. 29 (6), 534-538.

Goyette, B., Vigneault, C., Wang, N., Raghavan, V., 2011. Conceptualization, design and evaluation of a hyperbaric respirometer. J. Food Eng. 105 (2), 283-288.

Goyette, B., Vigneault, C., Raghavan, V., Charles, M.T., 2012a. Hyperbaric treatment on respiration rate and respiratory quotient of tomato. Food Bioprocess Technol. 5 (8), 3066-3074.

Goyette, B., Vigneault, C., Charles, M.T., Raghavan, V.G., 2012b. Effect of hyperbaric treatments on the quality attributes of tomato. Can. J. Plant Sci. 92 (3), 541-551.

Goyette, B., 2010. Hyperbaric Treatment to Enhance Quality Attributes of Fresh Horticultural Produce. Department of Bioresource Engineering McGill University, Montreal Quebec, Canada Doctoral thesis.

Guo, Q., Wu, B., Peng, X., Wang, J., Li, Q., Jin, J., Ha, Y., 2014. Effects of chlorine dioxide treatment on respiration rate and ethylene synthesis of postharvest tomato fruit. Postharvest Biol. Technol. 93, 9-14.

Javanmardi, J., Kubota, C., 2006. Variation of lycopene, antioxidant activity, total soluble solids and weight loss of tomato during postharvest storage. Postharvest Biol. Technol. 41 (2), 151-155.

Kader, A.A., 2002. Postharvest biology and technology: an overview. In: Kader, A.A. (Ed.), Postharvest Technology of Horticultural Crops. University of California, Davis, California, pp. 43-54. 
Kantola, M., Helén, H., 2001. Quality changes in organic tomatoes packaged in biodegradable plastic films. J. Food Qual. 24 (2), 167-176.

Kim, J.Y., Lee, J.S., Kwon, T.R., Lee, S.I., Kim, J.A., Lee, G.M., Park, S.C., Jeong, M.J., 2015. Sound waves delay tomato fruit ripening by negatively regulating ethylene biosynthesis and signaling genes. Postharvest Biol. Technol. 110, 43-50.

López Camelo, A.F., Gómez, P.A., 2004. Comparison of color indexes for tomato ripening. Hortic. Bras. 22 (3), 534-537.

Liplap, P., Vigneault, C., Toivonen, P., Charles, M.T., Raghavan, G.V., 2013a. Effect of hyperbaric pressure and temperature on respiration rates and quality attributes of tomato. Postharvest Biol. Technol. 86, 240-248.

Liplap, P., Charlebois, D., Charles, M.T., Toivonen, P., Vigneault, C., Raghavan, G.V., 2013b. Tomato shelf-life extension at room temperature by hyperbaric pressure treatment. Postharvest Biol. Technol. 86, 45-52.

Liplap, P., Vigneault, C., Rennie, T.J., Boutin, J., Raghavan, G.V., 2014. Method for determining the respiration rate of horticultural produce under hyperbaric treatment. Food Bioprocess Technol. 7 (9), 2461-2471.

Malundo, T.M.M., Shewfelt, R.L., Scott, J.W., 1995. Flavor quality of fresh tomato (Lycopersicon esculentum Mill.) as affected by sugar and acid levels. Postharvest Biol. Technol. 6 (1-2), 103-110.

Mattiuz, B.H., 2007. Fatores da pré-colheita influenciam a qualidade final dos produtos. Revista Visão Agrícola 7, 18-21.

Nagata, M., Yamashita, I., 1992. Simple method for simultaneous determination of chlorophyll and carotenoids in tomato fruit. Nippon Shokuhim Kogyo Gakkaishi 39 (10), 925-928.

Nascimento, A.D.R., Soares Júnior, M.S., Caliari, M., Fernandes, P.M., Rodrigues, J.P., de Carvalho, W.T., 2013. Quality of tomatoes for fresh consumption grown in organic and conventional systems in the state of Goias, Brazil. Hortic. Bras. 31 (4), 628-635.

Paniagua, A.C., East, A.R., Hindmarsh, J.P., Heyes, J., 2013. Moisture loss is the major cause of firmness change during postharvest storage of blueberry. Postharvest Biol. Technol. 79, 13-19.

Raghavan, G.S.V., Vigneault, C., Markarian, N.R., Gariépy, Y., Alvo, P., 2004.
Refrigerated and controlled/modified atmosphere storage. In: Barrett, D.M. Somogyi, L., Ramaswamy, H.S. (Eds.), Processing Fruits: Sciencie Technology. Boca Raton, Florida: CRC Press, pp. 23-52.

Saltveit, M., 2003. Temperature extremes. In: Bartz, J.A. (Ed.), Postharvest Physiology and Pathology of Vegetables. Marcel Dekker, Inc, New York, pp. 438-457.

Schouten, R.E., Woltering, E.J., Tijskens, L.M.M., 2016. Sugar and acid interconversion in tomato fruits based on biopsy sampling of locule gel and pericarp tissue. Postharvest Biol. Technol. 111, 83-92.

Smita, S., Rajwanshi, R., Lenka, S.K., Katiyar, A., Chinnusamy, V., Bansal, K.C., 2013. Expression profile of genes coding for carotenoid biosynthetic pathway during ripening and their association with accumulation of lycopene in tomato fruits. J. Genet. 92 (3), 363-368.

Stajčić, S., Ćetković, G., Čanadanović-Brunet, J., Djilas, S., Mandić, A., Četojević-Simin, D., 2015. Tomato waste: carotenoids content, antioxidant and cell growth activities. Food Chem. 172, 225-232.

Su, L., Diretto, G., Purgatto, E., Danoun, S., Zouine, M., Li, Z., Roustan, J., Bouzayen, M., Giuliano, G., Chervin, C., 2015. Carotenoid accumulation during tomato fruit ripening is modulated by the auxin-ethylene balance. Plant Biol. 15 (1), 114.

Türk, R., Seniz, V., Özdemir, N., Süzen, M.A., 1994. Changes in the chlorophyll carotenoid and lycopene contents of tomatoes in relation to temperature. Acta Hortic. $368,856-862$.

Tohge, T., Alseekh, S., Fernie, A.R., 2014. On the regulation and function of secondary metabolism during fruit development and ripening. J. Exp. Bot. 65 (16), 4599-4611.

Vigneault, C., Leblanc, D.I., Goyette, B., Jenni, S., 2012. Invited review: engineering aspects of physical treatments to increase fruit and vegetable phytochemical content. Can. J. Plant Sci. 92 (3), 373-397.

Wang, Y., Wang, B., Li, L., 2008. Keeping quality of tomato fruit by high electrostatic field pretreatment during storage. J. Sci. Food Agric. 88 (3), 464-470.

Zhu, T., Tan, W.R., Deng, X.G., Zheng, T., Zhang, D.W., Lin, H.H., 2015. Effects of brassinosteroids on quality attributes and ethylene synthesis in postharvest tomato fruit. Postharvest Biol. Technol. 100, 196-204. 